\title{
可操作性と回避可操作性を考慮した 冗長自由度マニピュレータの障害物回避動作計画
} \author{
manipulability \\ ○非 道木 加絵 (愛工大), 非 近藤聡士 (愛工大), 非 道木 慎二 (名大) \\ 非 舟洞佑記 (名大), 非 鳥井昭宏 (愛工大) \\ Kae Doki, Aichi Institute of Technology, doki@aitech.ac.jp \\ Satoshi Kondou, Aichi Institute of Technology, p12722pp@aitech.ac.jp \\ Akihiro Torii, Aichi Institute of Technology, torii@aitech.ac.jp \\ Shinji Doki, Nagoya University, doki@nagoya-u.jp \\ Yuki Funabora, Nagoya University, funabora@nagoya-u.jp
}

Motion planning of redundant manipulator for obstacle avoidance considering its manipulability and avoidance

\begin{abstract}
We propose a new motion planning method of a 7-DOF redundant manipulator. In this method, motion planning for obstacle avoidance is executed with the configuration space considering the actual range of joint motion. In addition, the manipulability and avoidance manipulability of the redundant manipulator are considered in the proposed motion method.
\end{abstract}

Key Words : 7-DOF redundant manipulator, Manipulability, Avoidance manipulability, Arm angle, Configuration Space

\section{1 はじめに}

近年、産業分野において汎用性の高い冗長マニピュレータが導 入されはじめているが、冗長マニピュレータのティーチングは作 業者に対して大きな負担となるため、冗長マニピュレータの動作 計画手法が望まれている。光こで、本研究では 7 自由度冗長マニ ピュレータを対象とした動作計画手法を検討する。

冗長マニピュレータの動作は手先位置、手先姿勢、腕姿勢から 構成される。見浪ら [1] は手先位置を与えたときの腕姿勢の計画 を目的とし、手先および腕の動きやすさについて検討した。また、 近藤 [2] は手先の目標位置を与えたときにマニピュレータの手先 および腕が障害物と衝突せずに目標位置に至る動作を計画した。 障害物との衝突や手先及び腕の動かしやすさは冗長マニピュレー 夕の作業能力を左右する重要な評価指標であるが、従来手法の動 作計画手法では個々に利用されてきた。乥こで、本研究では腕お よび手先の動かしやすさと障害物回避の両方を考慮し、手先及び 腕の動かしやすさを保ち、障害物を回避しつつ手先位置を与えら れた目標位置へ移動させる冗長マニピュレータの動作計画手法を 提案する。また本稿では害ロボットの関節の可動範囲を考慮する ことで実機で実現可能な動作計画を実現する。

2 障害物回避と動作性能を考慮した冗長マニピュ

$$
\text { レータの動作計画手法 }
$$

\section{1 問題設定と動作計画手法の概要}

本研究では図 1(a) に示す安川電機製 7 軸マニピュレータの MOTOMAN-SIA10D を使用する。このロボットをDH 記法で表 したモデルを図 1(b) に示す。本研究では手先姿勢を常に一定とす る。これは、作業内容に応じて手先姿勢は決められた一定値を取 ることが多いためである。弚の上で初期位置から障害物を回避し つつ与えられた目標位置に至る一連の動作を計画する。7 自由度 冗長マニピュレータは手先位置を表す 3 パラメータ、手先姿勢を 表す 3 パラメータ、冗長自由度を表す 1 パラメータの計 7 パラ メータが決定するとマニピュレータの逆運動学により各関節角を 求めることができる。よって、初期位置から目標位置までに至る 一連のこれらのパラメータを計画することでマニピュレータの動

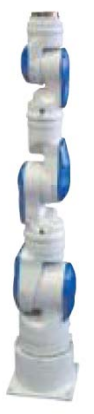

(a) MOTOMAN-SIA10D

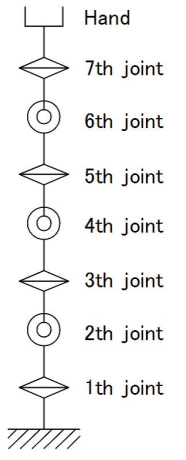

(b) Model of SIA 10D
Fig.1 Target manipulator for motion planning

作計画を行うことができる。本研究では手先姿勢は一定であるた め、提案手法では手先位置と腕姿勢からなるコンフィグレーショ ン空間を構成し、コンフィグレーション空間内でポテンシャル法 に基づき経路計画を行うことで動作計画を行う。

2.2 コンフィグレーション空間

コンフィグレーション空間 (以降 $\mathrm{C}$ 空間) を用いたマニピュ レータの動作計画は佐藤 [3] により提案されている。従来手法で はマニピュレータの各関節角を軸とした $\mathrm{C}$ 空間内でポテンシャル 法を用いて動作計画を実現している。この手法を適用する場合、 7 軸マニピュレータでは 7 次元の C 空間を構成することになるた め、動作計画が複雑になることが考えられる。光こで、本稿では 各関節角を軸とするのではなく、手先位置、手先姿勢、腕姿勢を 軸とした C 空間を構成する。ここで、腕姿勢を表すパラメータ としてアームアングル [4] を導入する。アームアングルは肘関節 の傾きであり、腕姿勢を表すパラメータである。この表現方法で は、手先位置、手先姿勢、腕姿勢のすべてを計画するには従来手 法を適用した場合と同樣の 7 次元空間が必要となる。しかし、本 研究で想定するような手先姿勢を一定とする作業の場合は手先姿 勢を表す 3 パラメータが省略でき、結果として手先位置とアーム 


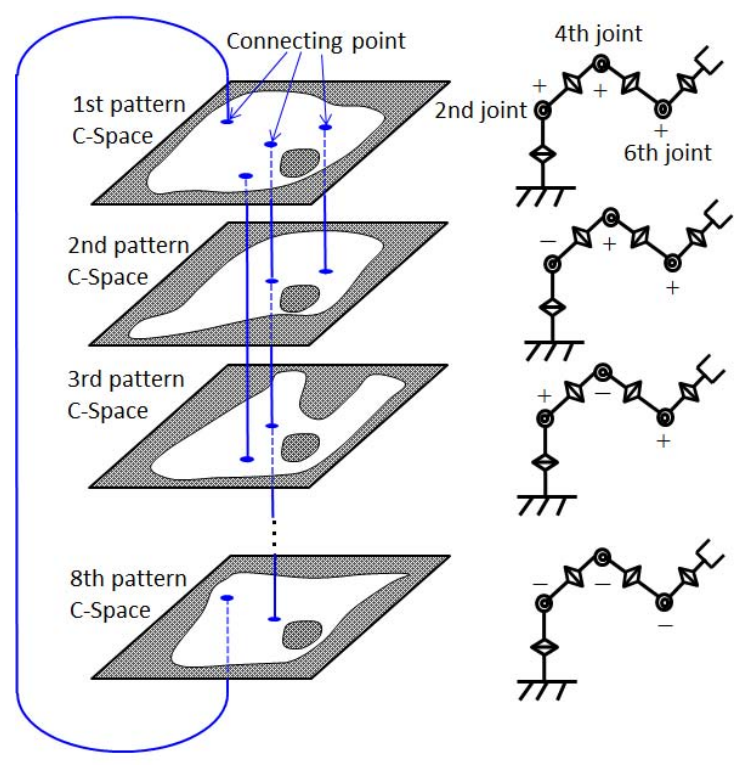

Fig.2 Image of constructed C-Space

アングルを表す 4 次元の C 空間を構成することになる。このよう に、手先位置、手先姿勢およびアームアングルにより C 空間を構 成することで、作業内容により計画の必要があるパラメータ数に 応じた次元数の C 空間を構成し、動作計画に必要な計算量を削減 する。

図 2 に本研究で用いる C 空間の概略図を示す。C 空間は手先位 置およびアームアングルから構成される 4 次元空間であり、8 パ ターン必要となる。これは、第 2 、第 4 、第 6 関節の正負の組み 合わせにより一つの手先位置およびアームアングルに対して 8 パ ターンの関節角が存在するためである。光こで各パターンごとに $\mathrm{C}$ 空間を構成することで関節角を一意に決定する。また、図のよ うにこれらの C 空間は弚れ午れ共有点と呼ばれる点で繋がってい る。共有点は第 $2 、$ 第 4、第 6 関節角のいずれかがゼロとなる点 であり、光の組合わせにより繋がる C 空間が異なる。また、C 空 間内には障害物と衝突する領域と関節の可動範囲外となる領域か らなる進入禁止領域が存在し、C 空間内において初期位置から C 空間内の進入禁止領域を回避しつつ目標位置に至る経路を生成す ることで初期位置から目標位置までの動作計画が得られる。

\section{3 ポテンシャル法を用いた経路計画}

文献 [3] の手法に基づき、極小点のないポテンシャル場 $E$ を C 空間内に生成する。ポテンシャル場 $E$ では初期位置と進入禁止領 域が最も高いポテンシャル、目標位置が最も低いポテンシャルと なる。このように生成したポテンシャル場に対し、提案手法では 可操作度 [5]、回避可操作度 [1] を考慮することで手先および腕 が動きやすい動作での障害物回避動作を計画する。具体的には、 $\mathrm{C}$ 空間内の各点におけるマニピュレータの可操作度を $V$ 、回避可 操作度を $W$ とすると、(1) 式となる。ここで、 $K_{V} 、 K_{W}$ は重みで ある。

$$
P=E+K_{V} \frac{1}{V}+K_{W} \frac{1}{W}
$$

このように生成されたポテンシャル場 $\mathrm{P}$ において、初期位置か ら $P$ が小さくる方向に経路を計画することで障害物を回避しつ つ可操作度、回避可操作度を高く保つ動作が計画を得ることがで きる。

\section{3 シミュレータを用いた動作計画実験}

本実験では、静止障害物がある環境で提案手法に基づきマニ ピュレータの動作を計画し、計画された動作から提案手法の有

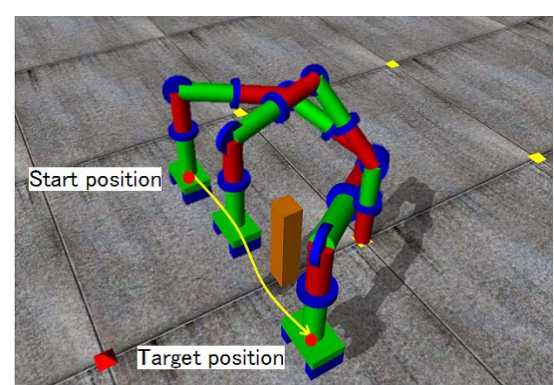

Fig.3 Planned motion

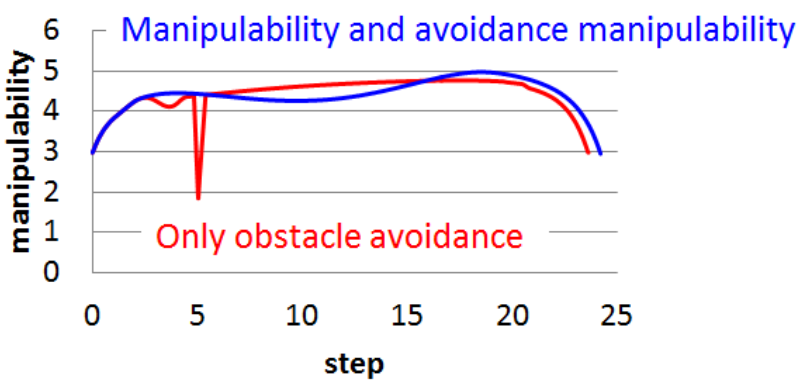

Fig.4 Planned joint angle

効性を検証する。ここで、マニピュレータの太さや障害物に対 する安全領域を確保するため実際に障害物が占有する空間より $50[\mathrm{~mm}]$ 広い範囲を進入禁止領域と設定した。関節の可動範囲は 対象とする実機ロボットと同じ第 1、第 3、第 5、第 7 関節が-175 〜+175[deg]、第 2、第 4、第 6 関節が-105〜+105[deg] である。

提案手法により計画された動作を図 3 に示す。図 3 は初期位 置から目標位置までのマニピュレータの動作を順に表している。 これらの結果から、障害物に干渉することなく手先が目標位置に 到達していることがわかる。計画された動作の可操作度の遷移を 図 4 に示す。障害物回避のみを行うと局所的に可操作度が低下す る動作計画が得られるが、提案手法では可操作度を高く保つ動作 計画が得られていることがわかる。

\section{4 まとめ}

本稿では、マニピュレータの動作性能を表す可操作性、回避可 操作性および各関節の可動範囲を考慮しながら障害物を回避する ためのマニピュレータの手先位置および腕姿勢を同時に計画する 手法を提案した。動作計画害験では、静止障害物のある環境にお いて提案手法により障害物を回避しつつ可操作度を高く保つ動作 が計画できることを確認した。

\section{文献}

[1] 見浪護、他, “冗長マニピュレータの回避可操作性”, 日 本ロボット学会誌, Vol.17,No.6, pp.133-141,1999

[2] 近藤浩一, ”ヒューリスティックなグラフ探索にもとづく 自由空間算出法による障害物回避動作計画”，日本ロボッ 卜学会誌, Vol.6,No.6, pp.21-30,1988

[3] 佐藤 圭祐, ”極小点のないポテンシャル場を用いた口 ボットの動作計画”, 日本ロボット学会誌, Vol.11No.5, pp.702-709,1993

[4] 清水晶幸、他, ”関節の可動範囲を考慮に入れた 7 自由度 冗長マニピュレータの解析的逆運動学”, 日本ロボット学 会誌, Vol.25,No.4, pp.606-617,2007

[5] 吉川 恒夫, ”ロボットアームの可操作度”, 日本ロボット 学会誌, Vol.2,No.1, pp.63-67,1984 